Curriculum, instruction, assessment, issues and concerns in the Saint Mary's University graduate school: Perspectives from stakeholders

Cachola, Susan G.

Saint Mary's University, Philippines (susancachola@yahoo.com)

Aduca, Ma. Cristeta

Saint Mary's University, Philippines (tetaaduca@yahoo.com)

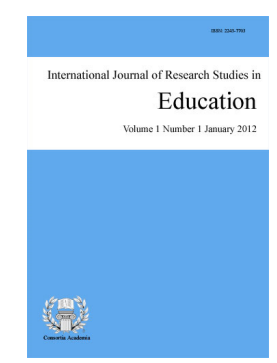

ISSN: 2243-7703 Online ISSN: 2243-7711

Valtoribio, Dominga

OPEN ACCESS

Saint Mary’s University, Philippines (dvaltoribio@gmail.com)

Guevara, Analyn

Saint Mary's University, Philippines (analyneguevara@yahoo.com)

\title{
Abstract
}

Graduate education is the apex of the educational system (Article XIII, Section 66, of the Manual of Regulations for Private Higher Education, 2008). The promotion and high level of achievement of demonstrated success and quality in teaching and scholarship on graduate levels manifest a higher education institute's academic excellence. Graduate education should take the lead role in enhancing the quality of Philippine higher education towards global competitiveness and world-class scholarship. As a Level III accredited Higher Education Institution, the Graduate School of SMU has a reasonably high standard of instruction, a highly visible research tradition and a strong faculty development programs (MORPHE, 2008). To maintain this academic recognition, the institution conducted assessment of its programs on the areas of curriculum, instructional materials, evaluation and grading, community service and involvement, library and physical facilities, admission and student services and research activities. This study employed the descriptive type of research through the use of the survey method, interview and focus group discussions with the faculty, alumni and the graduate students enrolled in the different graduate programs of the university. Results show that the provisions or conditions of all the areas of the graduate programs are moderately extensive and functioning well. Inasmuch as the Graduate School is now on its Level III status, the study recommends more comprehensive efforts to raise the provisions and conditions to a status of excellence.

Keywords: academic excellence; core areas; graduate education; graduate programs; higher education institution 


\section{Curriculum, instruction, assessment, issues and concerns in the Saint Mary's University graduate school: Perspectives from stakeholders}

\section{Accreditation of Higher Education Institutions}

The promotion and high level of achievement of demonstrated success and quality in teaching and scholarship on graduate levels manifest a higher education institute's academic excellence. Article XIII, Section 66, of the Manual of Regulations for Private Higher Education (CHED, 2008) states that graduate education is the apex of the educational system. As such, it shall showcase the best of the academic and intellectual process of the system. For these reasons, graduate education should be so structured as to enhance quality, efficiency and effectiveness in higher education. The programs of the graduate education should be more relevant in order to respond to the development needs of the educational system as well as the thrusts of the region and the nation. Furthermore, graduate education should take the lead role in enhancing the quality of Philippine higher education towards global competitiveness and world-class scholarship.

How does an educational institution achieve and maintain academic excellence? Pursuant to this dedication to achieve academic excellence, Article XIV, Section 69 (CHED, 2008) mandates that higher education institutions who desire to meet the standards of quality over and above the minimum required for government recognition submit themselves for voluntary accreditation. Through accreditation and continuous program reviews, the different graduate programs may continuously achieve academic excellence.

The Graduate School of Saint Mary's University (SMU) has been granted Level III accreditation by the Philippine Association of Accrediting Schools, Colleges and Universities (PAASCU) which indicates that the institution has a reasonably high standard of instruction and a highly visible research tradition (CHED, 2008). Moreover, as a Level III accredited institution, it manifests a strong faculty development programs. In addition, the institution also prides itself of an extensive and functional library and other learning facilities. To maintain this academic recognition, the institution has to conduct regular assessment of its programs. Feedbacks from accreditation and program reviews will strengthen the content, quality and support services of the various programs. Several core areas have to be continuously assessed.

\section{Core Areas of Accreditation}

Graduate programs are intended to be regular, ongoing, iterative processes that identify strengths and weaknesses of programs in achieving their intended outcomes and goals. As indicated by Calhoun Community College (n. d.) in terms of their program reviews, the overall purpose of program assessment and review is to evaluate each graduate program's quality and effectiveness, to stimulate program planning and improvement, and to encourage graduate degree programs to develop in directions that reflect the universities' strategic priorities. This is corroborated by Valtoribio and Tumaneng (2006) who indicated that through planned program review and assessment, each degree program systematically takes the time to evaluate challenges, strengths, weaknesses, and progress in achieving its goals. The quality of its faculty, entering students, graduates, and the overall quality of the academic experience as perceived by those associated with the program, both internally and externally, is the principal criterion of a graduate program's academic excellence. Thus, the assessment process will insure that the faculty members of the program are working effectively and students are receiving the best education possible.

Core areas refer to the congruence of the programs to national and local standards, as well as the practices being done to come up with a good and acceptable curriculum. Core areas in the graduate school's programs should therefore be evaluated and continually assessed. These core areas are curriculum, instruction, faculty, students' performance and library facilities. This is affirmed in the study of Ching (2012) which indicated that 
accreditation in the Philippines is mainly focused on quality of teaching and research, support for students, relations with the community, and management of resources.

\subsection{Program of studies and curriculum}

Curriculum is one of the most important outcomes of the schooling process. The study of Valtoribio and Buccahan (2010) defines curriculum as a plan that focuses and guides classroom instruction and assessment. A curriculum defines the contents that need to be acquired; the structure on the course of teaching and the conditions that are essential for successful learning. Curriculum is important because it discusses rationale, aims and objectives, assessment, content, learning activities, teacher role, materials \& resources, grouping, location, and time. Ramakrishnan (2013) indicated that through curriculum, the needs of the society are interpreted and a structure that interprets those values into learning experiences for learner. The curriculum has to be continuously reviewed since it provides the basis for curriculum policy decisions, for feedbacks on continuous curriculum adjustments and processes of curriculum implementation. Curriculum is important because it is the container that holds the institutional knowledge of what was the best of past instruction.

\subsection{Instructional materials, procedures and techniques}

Instructional materials, procedures and techniques refer to the appropriateness and judiciousness of assessment practices in the Graduate School. Assessing the instructional materials, procedures and techniques used by educators is very important as indicated in the study of Ottenbreit-Leftwich, Glazewski, Newby, and Ertmer (2010) which found out that teachers who believe in the value of using technology-based instructional materials, procedures and techniques employ technology to respond to professional (e.g., creating customized classroom materials, improving classroom management by engaging students) and student needs (e.g., enhancing student comprehension, equipping students with technology skills).

\subsection{Evaluation and grading}

Evaluation and grading refers to how the various programs use the knowledge and skills of the students in the different subjects to respond to the needs of the communities. Aboulsoud (2011) indicated that evaluation or assessment, whether formative or summative, reveals the strengths and weaknesses of students. Evaluation and grading or assessment brings about positive impact on learning not only because it motivates and encourages to be involved in the process but also monitors and provides students with real-time feedback on their performance.

\subsection{Community service and involvement}

Community service and involvement deal with the institution's capacity to involve itself in the community to help contribute to its development. Community involvement refers to the effort of the institution to relate itself to national, regional and local imperatives of development through building community awareness and producing quality graduates in the professions and vocations that can contribute to welfare development. This also means that the institution should make its programs, structures and resources responsive to the needs of the Filipino youth that faces the challenge of nation building. This should be manifested in programs, projects and activities which are well planned, organized, implemented, evaluated and supported by the institutions (Conchada \& Tiongco, 2015).

\subsection{Library}

Library refers to the availability and adequacy of needed print and non-print materials in the learning resource center. Academic support services, such as the library facilities, make a tremendous contribution to student learning on campus. Whether the impact on student learning is direct or indirect, all programs can assess how they contribute to the learning community and what changes they might make to maximize that learning experience. For example, teachers teach better and students learn better in a clean, comfortable environment with 
adequate desks and state-of-the-art instructional resources. Library and internet facilities are also important core areas of the graduate school inasmuch as these are invaluable tools in the conduct of any research undertaking.

One of the important factors in accreditation is considering the facilities for learning particularly library. It is of paramount importance to both students and faculty as it is a vital component of the academic environment. It should contain and provide access to information resources essential for members of the academic community. This goes to say that the library should have a mission statement, vision statement and goals to serve as a framework. The mission and goals should be consistent with the institution. Of equal importance are the inputs such as collections, personnel, financial support, administrative support and physical facilities. On the other hand, outputs are also considered such as number of books purchased, catalogued, circulated, number of reference questions answered. The third important factor is outcomes that pertain to the impact of the library's resources and programs on stakeholders. The available technology, greater use of online services, skills and increasing participation in information networks are also considered (PAASCU Undergraduate Survey Instrument, 2010).

\subsection{Physical facilities}

Physical facilities refer to how the systems of procedures in admission and retention are being observed. It also refers to the mechanisms and support services that can help students overcome the challenges in their coursework and the availability and adequacy of furniture and fixtures in the libraries. Part of the criteria includes an evaluation of site, campus, buildings, equipment and building services. First, the site should be located in a wholesome environment and should be provided with adequate facilities for drainage and sewage disposal. The campus should be planned so it will be adequate for the social, physical, cultural, and religious needs of the school. It should also be provided with sufficient facilities for intramural programs and for physical education classes and athletic activities. Buildings should be functionally designed and at the same time conducive to a quiet and serious learning environment. They should be well-planned to include entrances and exits enough for the population and to meet future expansion needs. In terms of building services, it should be well-illuminated and well-ventilated. The size and number of classrooms should be sufficient to accommodate the population. Moreover, there should be ample facilities for other services such as an auditorium, gymnasium, food areas, office and staff room, student activity areas, and clinic (PAASCU Survey Instrument, 2005).

\subsection{Admission, retention and student services}

The institution should also be a venue for students to develop their personality. Thus, a program of student services is deemed as an integral part. The findings of Clewell and Ficklen (1986) indicated elements that of successful retention efforts. These elements consist of policy on enrollment, a high level of institutional commitment, comprehensive student services, systematic collection of data, and strong faculty support. The PAASCU Undergraduate Survey Instrument (2005) indicated that program for student services should be in line with the vision, mission and goals and it should be supported by physical facilities and adequate financial resources. Second, the admissions program should provide for the proper selection and direction of prospective students. Third, the institution should have an orientation program for new students as well as to reorient old students. Fourth, the institution should have a guidance program which should offer the following services: individual inventory service, testing, information service, individual and group counseling, and placement and follow-up services. Fifth, there should also be a well-organized student support services program that provides financial aid, health services among others. Next, the institution should provide a variety of relevant co-curricular activities that contribute to student development. Lastly, the alumni should be formally organized to draw on their resources for employment, support for development plans and other worthy activities.

\subsection{Research activities}

Research activities refer to the avenues and support activities through which the research skills of the students could be developed and enhanced. It is mandatory that graduate students be actively involved in 
research particularly the writing of a thesis or a dissertation. This task demands the application of knowledge and skills acquired during the course of the graduate study. A number of graduate students find such tasks very challenging for a number of reasons. Choice of thesis, completion time, suspension and extension of candidature, course work grades, agreement between examiners and the level of honors awarded were some of the structural components that were considered. The study of Buchmueller, Dominitz and Hansen (1999) showed that a graduate student who has previous research experience in graduate school such as working as a research assistant or submitting and publishing articles has subsequent publishing proficiency. Variables such as graduate school ranking, graduate school faculty size and its publishing proficiency, and individual demographic characteristics and academic experiences were also investigated.

\section{Issues and concerns of graduate students}

Another important concern is the issues and problems encountered by the graduate students during the course of their study in the university. L'Huillier (2014) indicated that most graduate students experience setbacks and doubts. Often, disagreement and difficulties occur which may have arisen from lack of communication. Ideally, expectations from both sides should have been discussed at the outset but it is never too late to address it if expectations are not met.

Another issue is with regard to absent advisers, overbearing advisers and advisers who go on sabbatical and other leave periods. The best way to address the problem is to arrange a meeting and to discuss a pattern of contact times which would suit both parties, explain that it would be welcome to take a more leading role in planning and conducting research. Moreover, overload in teaching units as well as other commitments is also another great concern. In addition, some graduate students lack motivation especially when it comes to thesis or dissertation writing. When motivation to do such tasks is low, writing and completing the thesis and dissertation becomes one of the biggest challenges.

Studies have been conducted to assess the different graduate programs of higher educational institutions. In the study of Kretovics (1999), results indicate that the MBA program studied does increase the learning skills of its participants compared to entering student scores and a control group and that an MBA program does add value to students that is not necessarily obtained through work experience alone.

Assessment of the graduate programs is indeed mandatory inasmuch as these programs require high standards of excellence in order to determine whether gaps in the expected standards occur. There is a need for continuous evaluation of the different programs which also calls for periodic outcomes assessments. The relevance of the programs to the graduates' work should also be monitored. This is the focus of the study of Davis, Misra, and Van Auken (2002) which described the process for conducting an outcomes assessment and the results of an actual alumni assessment encompassing skill and knowledge areas. Specifically, they employed a gap analysis approach. Using this approach, they contrasted the importance of key skill and knowledge areas to one's current employment with perceptions of their own academic preparation in these areas. The results indicated that the marketing alumni perceive that they are underprepared in skills and over-prepared in designated knowledge areas.

This finding is affirmed by the study of Aiken, West, Sechrest, et al. (1990) which assessed the extent to which advances in statistics, measurement, and methodology have been incorporated into doctoral training. Results of the study indicated that the curriculum on statistics and research methodology has advanced little in $20 \mathrm{yrs}$. Moreover, the new $\mathrm{PhDs}$ are judged to be competent to handle traditional techniques, but not newer and often more useful procedures, in their own research. The study proposed interventions for these deficiencies which include revamping the basic required quantitative and methodological curriculum and culling available training opportunities across campus. In addition, the administration provided training for students in more informal settings as well as retraining opportunities for faculty. These are the capital needs of the graduate students that seek support for high-quality quantitative and methodological training and practice. 
The graduate programs should be relevant to the needs of the graduate students inasmuch as competencies must be manifested and practiced in their own respective fields. Thus, Rubin and Dierdorff (2009) investigated the relevancy of MBA curricula in relation to managerial competency requirements. Results indicated that behavioral competencies manifested by managers to be most critical are the very competencies least represented in required MBA curricula. Findings further indicate that institutional factors such as media rankings and mission orientation have no effect on the alignment of MBA curricula with critical managerial competencies. The findings indicated by Rubin and Dierdorff (2009) constitute a major challenge to the MBA education. MBA graduates must develop the ability to use management knowledge. Thus, a research was conducted by Boyatzis, Stubbs, and Taylor (2002) which found out that cognitive and emotional intelligence competencies can be developed in MBA students, but not with a typical MBA curriculum.

Lastly, the issues and concerns of the graduate students are noteworthy of attention since they spell the difference in the graduate students' success or failure. Foremost among these issues is the writing of the thesis or the dissertation. Indeed, graduate studies could pose considerable amount of stress because of the rigor of such undertaking. This is corroborated in the study of Toews et al. (1997) concerning medical students, residents and graduate students which indicated that among the three groups, there were significant differences between the three groups in the natures and degrees of stress, with the graduate students reporting higher levels of stress. There were significant gender differences as well, with the women reporting higher levels of stress. Overall, stress levels were found to be mild, based on the University of Calgary Stress Questionnaire and the SRRS. The study suggests that medical students and residents experience stress at levels that appear acceptable, but ongoing monitoring and the provision of appropriate support systems will continue to be important.

\subsection{Statement of the Problem}

The study aimed to assess the graduate programs of Saint Mary's University along the areas of curriculum content, faculty, instruction, evaluation of learning outcomes and laboratory and library facilities as well as determine the issues and concerns of the stakeholders in the course of their study. Specifically, this study sought to determine the respondents' assessment of the graduate programs along the areas of program of studies and curriculum, instructional materials, procedures and techniques, evaluation and grading, community service and involvement, library, physical facilities, admission, retention and student services, and research activities. This study also determined the issues and concerns encountered by the respondents in the course of their study.

\subsection{Significance of the Study}

This study is useful to the SMU Administration inasmuch as the results of the study would provide feedbacks as to the status of the different programs in the Graduate School which will serve as basis in any curriculum planning and improvement of physical facilities. The Faculty of the Graduate School Programs will be provided feedbacks on the strengths and weaknesses of the different core areas which will serve as basis for enhancement or improvement of the different programs and effective implementation of the programs. Graduate Students will be provided with accurate assessments of the programs they are currently taking. Their issues and concerns related to their courses will also be given attention and properly addressed. The University Learning Resource Center will be provided feedbacks which will serve as basis for the improvement of the library facilities and services. Future researchers who will conduct studies along this field will be provided with additional related literature which may help enrich their researches.

\subsection{Scope and Delimitation}

This study is limited to the assessment of program of studies and curriculum, instructional materials, procedures and techniques, evaluation and grading, community service and involvement, library, physical facilities, admission, retention and student services, research activities and the issues and concerns of the graduate students in the course of their study. This study is, therefore, limited to the faculty, alumni and graduate 
students who are enrolled in the school year 2014-2015.

\section{Conceptual Framework}

This research assessed the different program areas of the Graduate School along the core areas of curriculum, instruction, students' performance and library facilities as well as the issues and concerns of the graduate students in the course of their study. The profile of the respondents was studied. The sex of the respondents was included since the problems they may encounter may be sex specific. Age may also influence the respondents' assessment of the different core areas of the programs they are enrolled in as well as their issues and concerns.

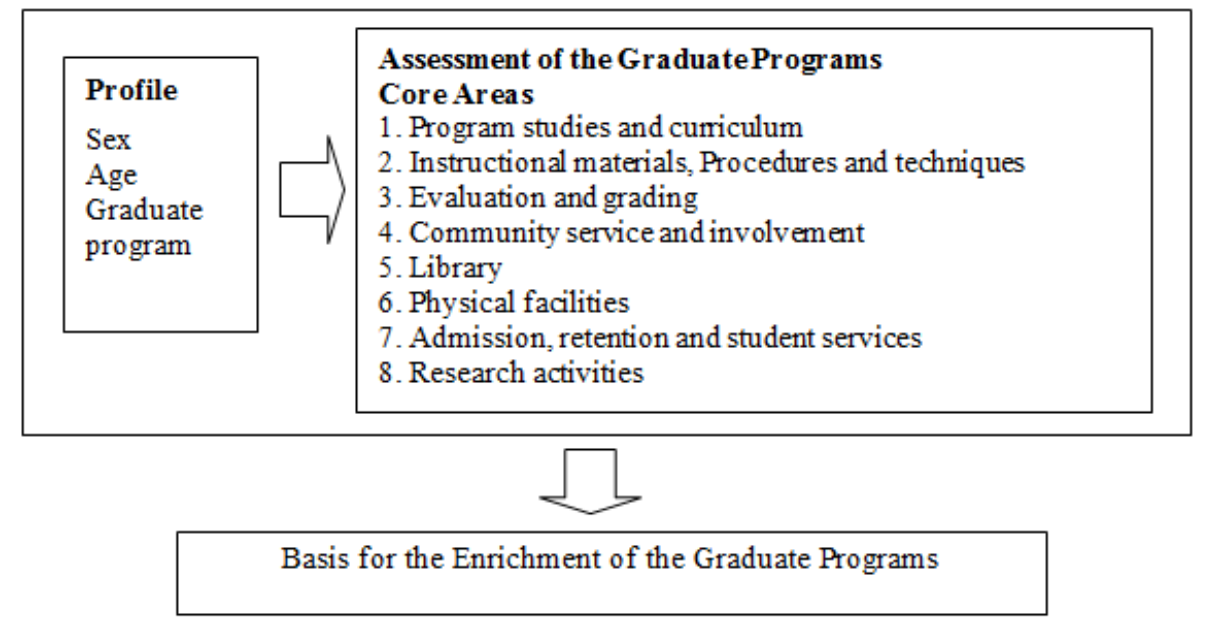

Figure 1. Research Paradigm

The Graduate program in which the respondents are enrolled in was also investigated inasmuch as their assessment and concern may be specifically true to a particular program. The different core areas of the different graduate programs were assessed. Curriculum which consists of the subjects and their contents was assessed to determine whether these subjects are relevant to the respondents' field of specialization, provide competencies needed by the graduates, have adequate and logical scope of topics and include latest developments in the field. Instruction was included to find out the faculty's use of adequate and varied reference materials, provision of opportunities for the enhancement of thinking skills, use of appropriate and varied instructional materials and productive use of class time. The area of faculty was also studied to determine whether the faculty has appropriate degree and manifest excellence, innovation, communion and passion for Christ's mission. Likewise, the students' performance was looked into to determine whether the assessment is relevant and focused, judicious and attainable, useful and functional to actual teaching-learning situation and has clear criteria for evaluating students' performance. The results of this endeavor will be the basis for the enrichment of the Graduate Programs in the coming school year.

\section{Research Methodology}

\subsection{Research Design}

The purpose of this study was to conduct an assessment on the curriculum, instruction, issues and concerns in the graduate school programs from the perspectives of the stakeholders. This study employed the descriptive type of research through the use of the survey method, interview and focus group discussions. These methods were considered to gather the data that will serve as basis in the enrichment of the graduate programs.

\subsection{Research Environment}

The study was conducted at Saint Mary's University during the school year 2014-2015. Saint Mary's 
Cachola, S. G., Aduca, M. C., Valtoribio, D., \& Guevara, A.

University is a Catholic higher educational institution in Bayombong, Nueva Vizcaya. It is a sectarian school founded by the Congregatio Immaculati Cordis Mariae (CICM) missionaries.

The 2012 edition of SMU Graduate School Handbook clearly points out that the School has been envisioned as a caring and dynamic center of professional service and development committed to nurturing competent, creative, and community-supportive Christian professionals by vigorously guiding, passionately empowering and continuously challenging them to develop their utmost potentials with proper values, attitudes and insights for local and global relevance, and for exploring and pursuing relevant, innovative and breakthrough ideas through research and development.

The Graduate School of Saint Mary's University has been granted Level II accreditation by the Philippine Association of Accrediting Schools, Colleges and Universities (PAASCU) which indicates that the institution has a reasonably high standard of instruction and a highly visible research tradition (MORPHE, 2008). Moreover, as a Level II accredited institution, it manifests a strong faculty development programs. In addition, the institution also prides itself of an extensive and functional library and other learning facilities.

\subsection{Respondents of the Study}

The respondents of the study were the SMU graduate faculty, alumni from year 2010-2014 and the graduate students enrolled in the different graduate programs of the university during the school year 2014-2015. The 223 stakeholders involved in the survey consisted of 143 females $(64.1 \%)$ and 80 males (35.9\%).57\% of the stakeholders in the survey comprised of students, $27.8 \%$ were alumni and 15.2 were faculty members.

\subsection{Research Instrument}

The tool employed in the gathering of data was based on the evaluation tool used by PAASCU team for graduate education. The tool involves the following areas: program of studies and curriculum; instructional materials, procedures and techniques; evaluation and grading; community service and involvement; library; physical facilities; admission, retention and student services; and research activities. The reliability analysis indicates that the instrument is reliable as indicated by the Cronbach's alpha of .98.

\subsection{Treatment of Data}

The rating scale adapted from PAASCU criteria was used in the interpretation of data:

\begin{tabular}{|ll|}
\hline 1 & Poor - The provision or condition is limited and functioning poorly \\
2 & Fair - The provision or condition is limited and functioning minimally \\
3 & Good - The provision or condition is met and functioning adequately \\
4 & Very Good- The provision or condition is moderately extensive and functioning well \\
5 & Excellent - The provision or condition is very extensive and functioning perfectly \\
6 & Not applicable - The provision or conditions are missing but do not apply or are not desirable
\end{tabular}

Descriptive statistical tools were used to analyze the quantitative data. For the profile of the respondents, frequency counts and percentages were used. For the evaluation of the different programs based on the core areas like curriculum, instruction, instructional materials, faculty, assessment, research and library and laboratory services, mean and standard deviations were utilized. Qualitative data were taken from the respondents' written issues and concerns in the questionnaire. Focus group discussions were also conducted to validate the written responses of the stakeholders.

\section{Results}

\subsection{Program of Studies and Curriculum}


All items in this area were rated very good. The highest mean (4.30) was given to the items about the programs being consistent with the institutional goals, and the requirements being able to prepare students to conduct research. This is confirmed in one verbatim written comment by one of respondents who indicated that the programs are consistent with the institutional goals, however, "...there is a need to continuously update the curriculum to keep itself abreast with national goals and needs of the times."

\section{Table 1}

Respondents' Assessment on Program of Studies and Curriculum

\begin{tabular}{|c|c|c|c|c|}
\hline Statements & Mean & Median & $\mathrm{SD}$ & QD \\
\hline $\begin{array}{l}\text { 1. The program of studies is consistent with: } \\
\text { a. Philippine national goals }\end{array}$ & 4.12 & 4.00 & .75 & Very good \\
\hline b. the institutional goals & 4.30 & 4.00 & .68 & Very good \\
\hline c. the specific objectives of the course & 4.28 & 4.00 & .72 & Very good \\
\hline $\begin{array}{l}\text { 2. The program of studies consists of systematically arranged } \\
\text { learning experiences that are interdisciplinary and } \\
\text { multi-disciplinary. }\end{array}$ & 4.14 & 4.00 & .71 & Very good \\
\hline $\begin{array}{l}\text { 3. The program of studies reflects the professional and technical } \\
\text { preparation needed by the graduate students. }\end{array}$ & 4.22 & 4.00 & .70 & Very good \\
\hline $\begin{array}{l}\text { 4. The curriculum is well-defined, providing depth and breadth in: } \\
\text { a. foundation courses }\end{array}$ & 4.22 & 4.00 & .66 & Very good \\
\hline b. professional courses & 4.24 & 4.00 & .64 & Very good \\
\hline $\begin{array}{l}\text { 5. The requirements in the different subjects prepare the graduate } \\
\text { students to undertake research. }\end{array}$ & 4.30 & 4.00 & .70 & Very good \\
\hline $\begin{array}{l}\text { 6. Periodic evaluation keeps curricular offerings abreast with the } \\
\text { times. }\end{array}$ & 4.04 & 4.00 & .70 & Very good \\
\hline $\begin{array}{l}\text { 7. Evaluation of the program of studies considers flexibility of } \\
\text { offerings in major fields. }\end{array}$ & 4.02 & 4.00 & .72 & Very good \\
\hline $\begin{array}{l}\text { 8. Faculty members participate in the evaluation and revision of } \\
\text { the curriculum. }\end{array}$ & 4.09 & 4.00 & .85 & Very good \\
\hline $\begin{array}{l}\text { 9. Students participate in the evaluation and revision of the } \\
\text { curriculum. }\end{array}$ & 3.53 & 4.00 & 1.11 & Very good \\
\hline
\end{tabular}

The lowest mean (3.53), although it was still rated as good, was given to the item about students' participation in curriculum revision. This is expected because not everyone is really involved. Usually, only the faculty members and selected student representatives are given the chance to sit in the Committee on Curriculum revisions. Moreover, there are programs which have not yet undergone curriculum revisions like PhD Commerce, MSA, MIT, MPA and Master in Engineering. The programs have just started producing graduates in 2012. Revisions may be conducted in 2015. In addition, a stakeholder's verbatim written comment stipulated that “...the curriculum in the graduate studies of SMU is indeed well planned excellently but as I have noticed, some courses being indicated on it is/are not at par with the latest trend that exists in the modern world." Hence, the need to conduct curriculum revisions is a necessity.

\subsection{Instructional Materials, Procedures and Techniques}

The item that topped the list is the one on smooth flow of communication between faculty and students (mean $=4.24)$. This is in consonance with the vision-mission of SMU Graduate School to become a caring and dynamic center of professional service and development that guides, empowers and challenges professionals to pursue excellence, innovation, and passion for Christ's mission (Graduate School Handbook, 2015).

The two other items that topped the list are the ones on syllabus being required in each subject $($ mean $=$ 4.22 ), and availability of laboratories for laboratory courses (mean $=22$ ). Truly, syllabi for all subjects and appropriate laboratories for subjects that need one are always made available. The lowest mean score (3.99) was given to the item on the use of varied methods and approaches. The lowest mean (3.99), although still rated as very good is found in the item on variety of methods and approaches used. This is confirmed in a verbatim 
Cachola, S. G., Aduca, M. C., Valtoribio, D., \& Guevara, A.

statement of a respondent who commented that, “...instruction in the graduate school is diversified - there should be a concrete way of addressing strategies which are responsive to the existing needs of graduate students." This indicates that the graduate students clamor for the utilization of wide-ranging methods and approaches that would address their needs.

Table 2

Respondents' Assessment on Instructional Materials, Procedures and Techniques

\begin{tabular}{|c|c|c|c|c|}
\hline Statements & Mean & Median & SD & QD \\
\hline 1. An approved syllabus is required for each subject. & 4.22 & 4.00 & .75 & Very good \\
\hline $\begin{array}{l}\text { 2. The syllabus is updated periodically to keep abreast with the } \\
\text { times. }\end{array}$ & 4.12 & 4.00 & .79 & Very good \\
\hline 3. The syllabus indicates opportunities for independent study. & 4.17 & 4.00 & .78 & Very good \\
\hline 4. The syllabus indicates training in research methodology. & 4.09 & 4.00 & .72 & Very good \\
\hline $\begin{array}{l}\text { 5. Instructional materials have depth and breadth expected on the } \\
\text { graduate level. }\end{array}$ & 4.12 & 4.00 & .69 & Very good \\
\hline $\begin{array}{l}\text { 6. Instructional materials reflect development of desirable attitudes } \\
\text { towards graduate education and its concomitant values. }\end{array}$ & 4.09 & 4.00 & .70 & Very good \\
\hline 7. Instructional materials provide training in research. & 4.01 & 4.00 & .76 & Very good \\
\hline $\begin{array}{l}\text { 8. Students make extensive use of books, readings, handouts, } \\
\text { audio-visual materials, and computer software as a part of program } \\
\text { requirements. }\end{array}$ & 4.13 & 4.00 & .77 & Very good \\
\hline 9. Laboratories are available for laboratory courses. & 4.22 & 4.00 & .96 & Very good \\
\hline 10. Teaching methods are suited to subject content. & 4.14 & 4.00 & .76 & Very good \\
\hline 11. Varied methods and approaches are used. & 3.99 & 4.00 & .78 & Very good \\
\hline $\begin{array}{l}\text { 12. Instructional procedures and techniques in the classroom } \\
\text { encourage active faculty and student interaction. }\end{array}$ & 4.13 & 4.00 & .72 & Very good \\
\hline $\begin{array}{l}\text { 13. There is a smooth flow of communication between faculty and } \\
\text { students. }\end{array}$ & 4.24 & 4.00 & .76 & Very good \\
\hline $\begin{array}{l}\text { 14. Interdisciplinary and multi-disciplinary approaches are used } \\
\text { whenever possible. }\end{array}$ & 4.11 & 4.00 & .73 & Very good \\
\hline 15. Seminars, fora, symposia and others are utilized. & 4.04 & 4.00 & .84 & Very good \\
\hline $\begin{array}{l}\text { 16. Methods and strategies contribute to the development of } \\
\text { desirable values. }\end{array}$ & 4.06 & 4.00 & 67 & Very good \\
\hline $\begin{array}{l}\text { 17. Define rules and policies for good classroom management are } \\
\text { defined and enforced. }\end{array}$ & 4.07 & 4.00 & .80 & Very good \\
\hline
\end{tabular}

This is corroborated by the study of Aiken et al. (1990) which focused on graduate training in statistics, methodology, and measurement in Psychology $\mathrm{PhD}$ programs in North America. The study proposed interventions for deficiencies in the quantitative and methodological curriculum and provided training for students since these are the capital needs of the graduate students that seek support for high-quality quantitative and methodological training and practice. Despite the differences in the mean and median values, the qualitative descriptions remain the same. The graduate programs along the area of instructional materials, procedures and techniques were considered very good by the faculty, alumni and students.

\subsection{Evaluation and Grading}

Generally, the area on evaluation and grading was found very good by the stakeholders. The highest mean values were given to the items on comprehensive examinations, ranging from 4.33 to 4.37 . The results indicate that the faculty members are aware of the sound principles in assessing student performance and learning outcomes, and they are able to implement effectively the principles that are necessary and appropriate for the graduate level.

The lowest mean (4.20), although still rated very good, is on the faculty members' use of valid techniques to evaluate student performance. As indicated by verbatim comments from several respondents, the area on evaluation and grading “...is excellent; there is fairness in the grading and evaluation...carry on; it is accurate”; 
however, some respondents also indicated that "the evaluation and grading should be standard among instructors and they should use one policy in grading system; no rubrics established for evaluation and grading of research/concept papers". These verbatim comments suggest a more comprehensive effort to persistently elevate the provision on evaluation and grading.

Table 3

Respondents' Assessment on Evaluation and Grading

\begin{tabular}{|c|c|c|c|c|}
\hline Statements & Mean & Median & SD & QD \\
\hline $\begin{array}{l}\text { 1. Faculty members use valid techniques to evaluate } \\
\text { student performance. }\end{array}$ & 4.20 & 4.00 & .67 & Very good \\
\hline 2. The grading policy is well-defined. & 4.21 & 4.00 & .74 & Very good \\
\hline 3. The grading policy is made known to the students. & 4.23 & 4.00 & .80 & Very good \\
\hline $\begin{array}{l}\text { 4. Researches, term papers, projects and other } \\
\text { requirements reflect a scholarly level of achievement. }\end{array}$ & 4.22 & 4.00 & .70 & Very good \\
\hline $\begin{array}{l}\text { 5. Examinations measure the attainment of objectives } \\
\text { stated in the syllabi. }\end{array}$ & 4.33 & 4.00 & .70 & Very good \\
\hline $\begin{array}{l}\text { 6. Comprehensive examinations measure } \\
\text { a. the depth and breadth of students' competence and } \\
\text { performance }\end{array}$ & 4.36 & 4.00 & .74 & Very good \\
\hline b. knowledge of facts and principles & 4.37 & 4.00 & .71 & Very good \\
\hline c. command of written communication & 4.37 & 4.00 & .72 & Very good \\
\hline $\begin{array}{l}\text { d. the ability to organize and integrate ideas and } \\
\text { information }\end{array}$ & 4.34 & 4.00 & .71 & Very good \\
\hline e. the ability to analyze and synthesize ideas & 4.34 & 4.00 & .73 & Very good \\
\hline
\end{tabular}

\subsection{Community Service and Involvement}

This area obtained relatively low mean values compared with other areas. The syllabi have provisions for research, aside from other requirements. The students might not have realized that this is one way of guiding them to explore materials that will enable them to become aware of the community needs and problems and inspire them to be involved thereby developing more their ethical principles and values. Moreover, the Graduate School launched in 2010 the project Graduate Initiatives for Trainings, Empowerment and Development (GIFTED). Through this, all classes or graduate programs are encouraged to conduct seminars, fora, trainings, among others to reach out to other groups or institutions in the neighboring communities. Not all programs have participated in the Project; hence the students and alumni might not yet be fully aware of this. Nonetheless, the ratings still indicate that the graduate programs are still very good in the area of community service and involvement.

\section{Table 4}

Respondents' Assessment on Community Service and Involvement

\begin{tabular}{lcccc}
\hline Statements & Mean & Median & SD & QD \\
\hline $\begin{array}{l}\text { 1. Knowledge about the community is acquired through } \\
\text { scientific inquiry and research. }\end{array}$ & 4.03 & 4.00 & 2.12 & Very good \\
$\begin{array}{l}\text { 2. The graduate school provides activities and programs to } \\
\text { develop social awareness and concern in the students, } \\
\text { faculty and total school community. }\end{array}$ & 3.91 & 4.00 & .81 & Very good \\
$\begin{array}{l}\text { 3. The graduate school provides leadership in initiating } \\
\text { and maintaining development projects. }\end{array}$ & 3.90 & 4.00 & .87 & Very good \\
$\begin{array}{l}\text { 4. Ethical principles and values are promoted through } \\
\text { course, public seminars, projects, etc. }\end{array}$ & 3.98 & 4.00 & .83 & Very good \\
$\begin{array}{l}\text { 5. Community needs and problems are discussed in the } \\
\text { classroom as part of the course requirements/subject } \\
\text { matter coverage. }\end{array}$ & 3.91 & 4.00 & .83 & Very good
\end{tabular}




\subsection{Library}

Despite the fact that the Graduate School does not have a separate library, the ULRC has a section specifically for graduate programs. The other resources may be accessed in other specialized sections. Thus, this may be the reason for getting a very good rating (mean $=3.85$ ) for this item. Generally, physical facilities focused on the library. The very good rating in every item in this area indicates that somehow, the stakeholders are contented with what SMU graduate programs offer in terms of library facilities.

\section{Table 5}

Respondents' Assessment on Library

\begin{tabular}{|c|c|c|c|c|}
\hline Statements & Mean & Median & SD & QD \\
\hline $\begin{array}{l}\text { 1. The reading materials and references are broad, varied, } \\
\text { and up-to-date in the different majors and fields of } \\
\text { specializations. }\end{array}$ & 3.98 & 4.00 & .87 & Very good \\
\hline $\begin{array}{l}\text { 2. The collection of books, periodicals and other library } \\
\text { materials is adequate to support the demands of scholarship, } \\
\text { research and instruction of both faculty and students. }\end{array}$ & 4.04 & 4.00 & .87 & Very good \\
\hline $\begin{array}{l}\text { 3. There is a strong reference collection, for literature } \\
\text { search, background readings and information sources. }\end{array}$ & 4.02 & 4.00 & .90 & Very good \\
\hline $\begin{array}{l}\text { 4. Audio-visual materials such as maps, posters, pictures, } \\
\text { micro-materials, films and filmstrips and other instructional } \\
\text { non-print materials are provided and easily accessible } \\
\text { through adequate facilities and equipment. }\end{array}$ & 3.91 & 4.00 & .93 & Very good \\
\hline $\begin{array}{l}\text { 5. The library has regular subscriptions to appropriate } \\
\text { periodicals. }\end{array}$ & 3.97 & 4.00 & .89 & Very good \\
\hline $\begin{array}{l}\text { 6. It has at least three professional journals for every } \\
\text { curricular discipline. }\end{array}$ & 3.83 & 4.00 & .94 & Very good \\
\hline $\begin{array}{l}\text { 7. There is an accessible and adequate research system: } \\
\text { updated catalogs, vertical files, readers' guides/indices } \\
\text { including bibliography of theses and dissertations done by } \\
\text { graduates of the school. }\end{array}$ & 3.89 & 4.00 & .90 & Very good \\
\hline $\begin{array}{l}\text { 8. The library has special features/provisions to facilitate } \\
\text { graduate work and ensure maximum access and availability } \\
\text { of collections, such as carrels or areas where graduate } \\
\text { students can study undisturbed for hours. }\end{array}$ & 3.97 & 4.00 & .86 & Very good \\
\hline
\end{tabular}

\subsection{Physical Facilities}

\section{Table 6}

Respondents' Assessment on Physical Facilities

\begin{tabular}{|c|c|c|c|c|}
\hline Statements & Mean & Median & SD & QD \\
\hline $\begin{array}{l}\text { 1. The library is accessible from any point of activity } \\
\text { on campus. }\end{array}$ & 4.17 & 4.00 & .76 & Very good \\
\hline 2. The graduate school has a separate library. & 3.85 & 4.00 & 1.17 & Very good \\
\hline 3. The library is well-lighted. & 4.14 & 4.00 & .77 & Very good \\
\hline 4. The library is properly ventilated. & 4.04 & 4.00 & .88 & Very good \\
\hline $\begin{array}{l}5 \text {. The library provides an atmosphere conducive to } \\
\text { reading and study. }\end{array}$ & 4.10 & 4.00 & .84 & Very good \\
\hline $\begin{array}{l}\text { 6. The furniture and facilities are functionally and } \\
\text { aesthetically arranged. }\end{array}$ & 4.19 & 4.00 & .72 & Very good \\
\hline $\begin{array}{l}\text { 7. Adequate work space is provided for the library } \\
\text { staff. }\end{array}$ & 4.17 & 4.00 & .77 & Very good \\
\hline $\begin{array}{l}\text { 8. Adequate space and seating arrangements are } \\
\text { provided for library users. }\end{array}$ & 4.21 & 4.00 & .76 & Very good \\
\hline 9. The open-shelf system is adopted. & 4.30 & 4.00 & .68 & Very good \\
\hline
\end{tabular}


Despite the fact that the Graduate School does not have a separate library, the ULRC has a section specifically for graduate programs. The other resources may be accessed in other specialized sections. Thus, this may be the reason for getting a very good rating (mean $=3.85$ ) for this item. Generally, physical facilities focused on the library. The very good rating in every item in this area indicates that somehow, the stakeholders are contented with what SMU graduate programs offer in terms of library facilities.

\subsection{Admission, Retention and Student Services}

The table shows the stakeholders' assessment on admission, retention and students services. The highest mean (4.15) is found on the statement which indicates that the policies and practices of the selection and admission of graduate students are supportive of and conform to the goals and objectives of the institution. This is confirmed in the verbatim comments of the respondents such as: "graduate school service is very excellent, problems are entertained without delay and they provide assistance during inquiries; excellent; well done; student services: convenient rooms for graduate studies; very good!". Although all the items in this area were rated very good, there are four items that obtained relatively lower mean values compared to the other values. These include provision for competent referral system to deal with necessary services related to the quality production of thesis reports (mean $=3.99$ ); opportunities for financial assistance to students (mean $=3.89$ ); support services for research work (mean $=3.91$ ); and availability of auxiliary services such as guidance, dental, medical, among others $($ mean $=3.91)$.

\section{Table 7}

Respondents' Assessment on Admission, Retention and Student Services

\begin{tabular}{|c|c|c|c|c|}
\hline Statements & Mean & Median & SD & QD \\
\hline $\begin{array}{l}\text { 1. The policies and practices of the graduate school in the selection } \\
\text { and admission of prospective students (beginning / transfer students) } \\
\text { are consistent with government regulation. }\end{array}$ & 4.13 & 4.00 & .70 & Very good \\
\hline $\begin{array}{l}\text { 2. The policies and practices of the selection and admission of } \\
\text { graduate students are supportive of and conform to the goals and } \\
\text { objectives of the institution. }\end{array}$ & 4.15 & 4.00 & .66 & Very good \\
\hline $\begin{array}{l}\text { 3. The admission criteria for the selection and admission of graduate } \\
\text { students are effective in identifying students capable of doing graduate } \\
\text { work. }\end{array}$ & 4.09 & 4.00 & .70 & Very good \\
\hline $\begin{array}{l}\text { 4. The policies and criteria for the retention of students are clearly } \\
\text { stated and made known. }\end{array}$ & 4.09 & 4.00 & .76 & Very good \\
\hline $\begin{array}{l}\text { 5. The retention criteria used are effective in identifying and } \\
\text { motivating qualified students to complete the degree requirements. }\end{array}$ & 4.05 & 4.00 & .66 & Very good \\
\hline $\begin{array}{l}\text { 6. Minimum performance requirements enable graduate students to } \\
\text { meet degree requirements within acceptable time limits. }\end{array}$ & 4.04 & 4.00 & .72 & Very good \\
\hline 7. The retention criteria are applied fairly and consistently. & 4.04 & 4.00 & .74 & Very good \\
\hline $\begin{array}{l}\text { 8. There is a functional academic advising system for graduate } \\
\text { students. }\end{array}$ & 4.04 & 4.00 & .82 & Very good \\
\hline $\begin{array}{l}\text { 9. There is a competent referral system to deal with necessary services } \\
\text { related to the quality production of thesis reports. }\end{array}$ & 3.99 & 4.00 & .79 & Very good \\
\hline $\begin{array}{l}\text { 10. There are opportunities for financial assistance to students, such as } \\
\text { scholarships, financial grants, assistantships, etc. }\end{array}$ & 3.89 & 4.00 & .93 & Very good \\
\hline $\begin{array}{l}\text { 11. There are support services for research work and other } \\
\text { requirements. }\end{array}$ & 3.91 & 4.00 & .86 & Very good \\
\hline $\begin{array}{l}\text { 12. Auxiliary services such as guidance, dental, medical, etc. are } \\
\text { available. }\end{array}$ & 3.91 & 4.00 & .98 & Very good \\
\hline
\end{tabular}

The first one which is on quality production of thesis report and support services for research work may be true because graduate students on thesis writing usually look for facilities in the University that can do the binding and editing of the final draft. What the University has is service for editing but not for binding of documents for submission. Some students might also find not sufficient the discounts and scholarships being offered for graduate students. Only entrance scholars may apply for academic scholarship, and discounts are 
Cachola, S. G., Aduca, M. C., Valtoribio, D., \& Guevara, A.

offered only to graduates of SMU who are teaching in either public or private schools. Consequently, only those enrolled in the teacher education programs are able to avail of discounts. Students from other programs are not qualified to apply. The students might not be aware of the auxiliary services like guidance, dental and medical services or they fail to avail of the services because the clinics and offices are available only during weekdays and Saturday morning. This might explain the relatively low mean value of 3.91 .

\subsection{Research Activities}

The table shows the stakeholders' assessment on research activities of the Graduate School. The highest mean (4.36) is found on the statement which indicates that all research outputs of the graduate school are evaluated by a panel of competent persons. This finding is corroborated by a verbatim comment of a respondent who stated that the research activities in the Graduate School are "very rigid but excellent". The research activities in the graduate programs were found very good by the stakeholders. This may be due to the fact that the Research Center and the Graduate School collaborate with other units in the University in conducting activities that will enhance the stakeholders' competence in doing research. Research fora and paper conferences are conducted yearly either at the school level, regional, inter-regional or national level. Moreover, research requirement in various forms is clearly stipulated in the syllabus of every subject.

\section{Table 8}

Respondents' Assessment on Research Activities

\begin{tabular}{|c|c|c|c|c|}
\hline Statements & Mean & Median & SD & QD \\
\hline 1. Research is integral part of the course requirements. & 4.35 & 4.00 & .65 & Very good \\
\hline $\begin{array}{l}\text { 2. The graduate school takes the lead in initiating } \\
\text { research activities in the university. }\end{array}$ & 4.25 & 4.00 & .66 & Very good \\
\hline $\begin{array}{l}\text { 3. The graduate school actually maintains or links with a } \\
\text { research center. }\end{array}$ & 4.32 & 4.00 & .63 & Very good \\
\hline $\begin{array}{l}\text { 4. Research seminars, workshops and lectures for } \\
\text { students and faculty are regularly offered. }\end{array}$ & 4.12 & 4.00 & .76 & Very good \\
\hline $\begin{array}{l}\text { 5. Sufficient statistical assistance for research is } \\
\text { provided by qualified faculty members or consultants. }\end{array}$ & 4.05 & 4.00 & .73 & Very good \\
\hline $\begin{array}{l}\text { 6. Faculty members produce a fair amount of quality } \\
\text { researches regularly. }\end{array}$ & 3.91 & 4.00 & .83 & Very good \\
\hline $\begin{array}{l}\text { 7. Thesis/dissertation and other research outputs reflect } \\
\text { use of scientific approaches/methods, originality/novelty } \\
\text { of topic/area, acceptable standards of format of research } \\
\text { reporting. }\end{array}$ & 4.19 & 4.00 & .76 & Very good \\
\hline $\begin{array}{l}\text { 8. All research outputs of the graduate school are } \\
\text { evaluated by a panel of competent persons. }\end{array}$ & 4.36 & 4.00 & .73 & Very good \\
\hline
\end{tabular}

\subsection{Issues and concerns of the stakeholders}

Lastly, the issues and concerns of the graduate students are noteworthy of attention since they spell the difference in the graduate students' success or failure. Foremost among these are the stakeholders' concern on the writing of the thesis or the dissertation as indicated by the verbatim remarks from respondents such as "...research, data gathering, formulation of questionnaire for case study, how to ask and to evaluate the responses; what parameters to consider to have a comprehensive analysis." Another concern of the respondents is the addition of more reference books as well as subscription to journals. Moreover, the respondents also stipulated the need for pointers for review for comprehensive examination and the immediate release of the results of the said examination and concrete laboratories for related fields such as Guidance and Counseling.

\section{Conclusions}

The assessment on the core areas of Graduate Programs such as program studies and curriculum, 
instructional materials, procedures and techniques, evaluation and grading, community service and involvement, library, physical facilities, admission, retention and student services and research activities is very good which indicates that the provisions and conditions of all areas of the graduate programs are moderately extensive and functioning well.

Implications - Higher educational institutions should disseminate the results of the assessment conducted to improve or enhance the graduate programs and solicit stakeholders' ownership of the institution's goals and objectives. Continuing professional courses to faculty of graduate school for updating of knowledge on assessment and instruction through trainings and workshops should also be provided. Moreover, feedback mechanisms, for example, tracer studies on alumni that will strengthen program review should be developed.

Recommendations - Inasmuch as the Graduate School is now on its Level III status, the study recommends more comprehensive efforts to continually raise the provisions and conditions to a status of excellence.

Acknowledgement: We would like to acknowledge the Research and Community Development Council (RCDC) headed by our University President Rev. Fr. Renillo H. Sta. Ana and the University Research Center (URC) headed by Dr. Fe Yolanda Gatan-del Rosario for the approval and grant of this research project. This paper was presented in the International Conference and Interdisciplinary Research Presentation held on May 15-17, 2015 at National Educators' Academy of the Philippines, Teachers' Camp, Baguio City, Philippines.

\section{References}

Aboulsoud, S. H. (2011). Formative versus summative assessment. Education for Health, 24(2), 651.

Aiken, L. S., West, S. G., Sechrest, L., Reno, R. R., Roediger III, H. L., Scarr, S., .. \& Sherman, S. J. (1990). Graduate training in statistics, methodology, and measurement in psychology: A survey of PhD programs in North America. American Psychologist, 45(6), 721-734. https://doi.org/10.1037/0003-066X.45.6.721

Calhoun Community College. (n.d.). Program reviews. Retrieved from http://www.calhoun.edu/about-calhoun/planning-research-grants-administration/program-reviews

Ching, G. S. (2012). Higher education accreditation in the Philippines: A literature review. International Journal of Research Studies in Management, 2(1), 63-74.

Clewell, B. C., \& Ficklen, M. S. (1986). Improving minority retention in higher education: A search for effective institutional practices. ETS Research Report Series, 1(June), i-157. https://doi.org/10.1002/j.2330-8516.1986.tb00172.x

Commission on Higher Education. (2008). Manual of regulations for private higher education of 2008. Retrieved from http://www.ched.gov.ph/wp.../Manual-of-Regulations-for-Private-Higher-Education.pdf

Conchada, M. I. P., \& Tiongco, M. M. (2015). A review of the accreditation system for Philippine higher education institutions (No. 2015-30). PIDS Discussion Paper Series.

Kretovics, M. A. (1999). Assessing the MBA: what do our students learn? Journal of Management Development, 18(2), 125-136. https://doi.org/10.1108/EUM0000000004550

L'Huillier, N. (2014). PhD problems: When things go wrong. Retrieved from http://www.findaphd.com/advice/doing/phd-problems.aspx

Ottenbreit-Leftwich, A. T., Glazewski, K. D., Newby, T. J., \& Ertmer, P. A. (2010). Teacher value beliefs associated with using technology: Addressing professional and student needs. Computers \& Education, 55(3), 1321-1335. https://doi.org/10.1016/j.compedu.2010.06.002

Philippine Accrediting Association of Schools, Colleges and Universities (PAASCU). (2005). Survey Instrument.

Ramakrishnan, K. (2013). Chapter 2 literature review. Retrieved from http://studentsrepo.um.edu.my/5729/17/CHAPTER2_21march13.pdf

Toews, J. A., Lockyer, J. M., Dobson, D. J., Simpson, E., Brownell, A. K., Brenneis, F., ... \& Cohen, G. S. (1997). Analysis of stress levels among medical students, residents, and graduate students at four Canadian 
Cachola, S. G., Aduca, M. C., Valtoribio, D., \& Guevara, A.

schools of medicine. Academic Medicine, 72(11), 997-1002.

https://doi.org/10.1097/00001888-199711000-00019

Valtoribio, D., \& Buccahan, A. (2010). A preliminary assessment of issues and concerns of the School of Arts and Sciences undergraduate programs. Unpublished research, Saint Mary's University, Bayombong, Nueva Vizcaya, Philippines.

Valtoribio, D., \& Tumaneng, E. (2006). Stakeholders' assessment of teacher education programs. Unpublished research, Saint Mary's University, Bayombong, Nueva Vizcaya, Philippines. 